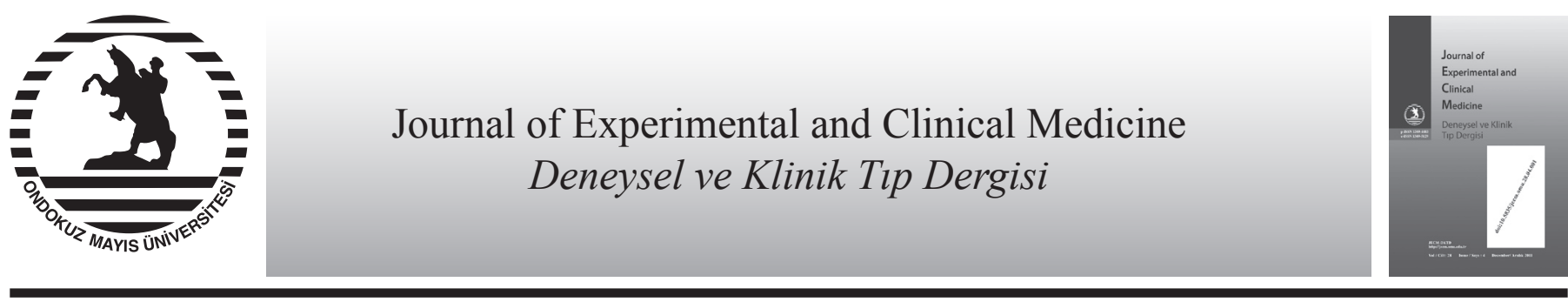

Olgu sunumu / Case report

doi: $10.5835 /$ jecm.omu.28.04.013

\title{
Inguinal hematom nedeniyle acil serviste takip edilen hemofili olgusu
}

\author{
A case of hemophilia followed in emergency department due to inguinal hematoma
}

\author{
Ali Kemal Erenlera", Türker Yardan ${ }^{\text {a }}$, Ahmet Baydın ${ }^{\text {a }}$, Mehmet Selim Nural ${ }^{\text {b }}$ \\ ${ }^{a}$ Ondokuzmayls Üniversitesi Acil Tıp Anabilim Dall, Samsun \\ ${ }^{b}$ Ondokuzmayıs Üniversitesi Radyodiyagnostik Anabilim Dall, Samsun
}

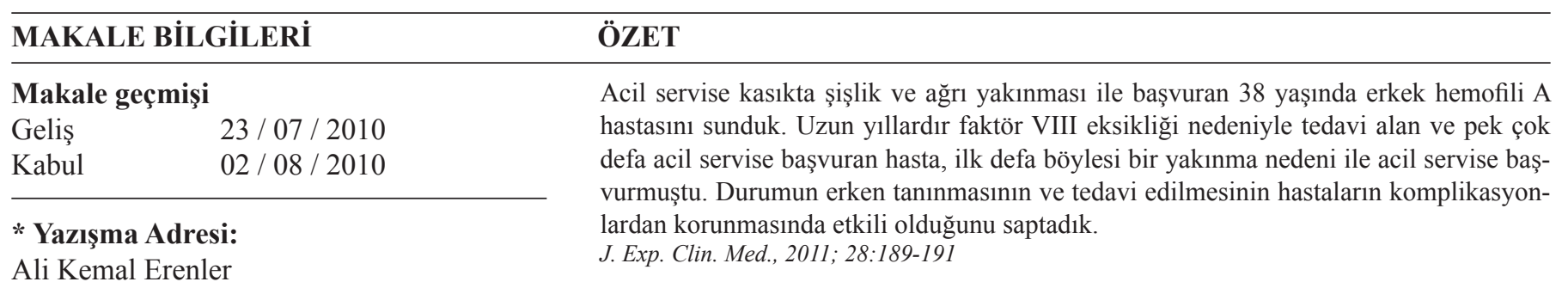

Ondokuz Mayıs Üniversitesi

Tıp Fakültesi Acil Tıp Anabilim Dalı,

Krupelit/Samsun

E-posta: akerenler@hotmail.com

\section{Anahtar Kelimeler:}

Acil servis

Hemofili A

İnguinal hematom

Ağr1

Komplikasyon

Kanama

\begin{abstract}
We described a case report of a 38-year-old male hemophilia A patient who presented to our emergency department with swelling and pain on groin. Although he was medicated for factor VIII deficiency for many years and visited our department for many other reasons, this was the first time he presented with such a complaint. We pointed out that early diagnosis and treatment of this condition is cruical for preventing patients from complications.
\end{abstract}

J. Exp. Clin. Med., 2011; 28:189-191

Keywords:

Emergency department

Hemophilia A

Inguinal hematoma

Pain

Complication

Bleeding

C 2011 OMÜ Tüm hakları saklıdır

\section{Giriş}

Hemofili A, en sık görülen kalıtımsal pıhtılaşma bozukluğu olup, pıhtılaşmayı sağlayan faktör VIII'in (FVIII) eksikliği ya da anormalliği durumunda ortaya çıkmaktadır (Connelly et al., 1998). X'e bağlı kalıtım yoluyla geçen bu hastalık, genel popülasyon göz önüne alındığında 5 ila 10.000'de 1 erkek bireyi etkilemekte ve 3 'te biri spontan genetik mutasyonlar sonucu gerçekleşmektedir (Connelly et al., 1998; Singleton et al., 2008). Bu hastalıktan etkilenen bireyler, genellikle eklemlere ve kas içine olan kanamalarla hastaneye başvurabilmekle beraber kan kaybına bağlı ölümler de görülebilmektedir (Nyugen et al., 2008). Hemofili A'nın musküloskeletal komplikasyonları arasında akut dönemde spontan ya da travmalara bağlı kanamalar, hematomların eşlik ettiği ve düşük enerjili travmalarla da oluşabilen kırıklar, yumuşak doku yaralanmaları ve eklem içine kanamalar, kronik dönemde ise güçsüzlük, paraliziler, kontraktürler, sinovit ve osteoartrit sayılabilir (Jones EW., 1958). Biz bu yazımızda, hemofili A tanısıyla takip edilen ve acil servisimize sağ kasık bölgesinde herhangi bir travma olmaksızın şişlik yakınmasıyla başvuran hastanın vaka raporunu sunduk.

\section{Vaka}

Otuz sekiz yaşında erkek hasta acil servisimize sağ kasığında şişlik yakınması ile başvurdu. Bu yakınmanın 2 gündür sürdüğünü belirten hasta bacağının üzerine basmakla ağrı oluştuğundan yakınmaktaydı. Herhangi bir travma öyküsü bulunmayan hastanın uzun yıllardır hemofili A ve hepatit $\mathrm{C}$ tanılarıyla takip edildiği ve en son bir gün önce hastaya $2 \times 500$ Ünite F VIII verildiği anamnezinden öğrenilmiştir. Bunun haricinde başka bir ilaç kullanım öyküsü bulunmamaktaydı. Yapılan fizik muayenesinde ateş: 36,5, kan basıncı: 120/90 
mmHg, solunum sayısı: 16/dakika, nabız: 56 vuru/dakika idi. Sistem incelemesinde kalp sesleri doğal, akciğer sesleri normaldi. Batın muayenesinde bombelik normal, hassasiyet, defans, rebound bulunmamakla beraber sağ femoral bölgede $4 \times 4 \mathrm{~cm}$ ebatlarında ekimotik olmayan palpasyonla redükte edilemeyen, ağriya neden olmayan şişlik tespit edildi. Her iki alt ekstremite arterleri elle alınabilmekte ve ekstremitelerde renk ve sıcaklık farkı bulunmamaktaydı. Hastaneye başvuru anında bakılan kan biyokimyasal parametreleri ve tam kan sayımı normal referans değerlerinde idi.. Hastanın aktive PTT değeri 47,6saniye, PT zamanı 11,4 saniye, INR değeri 1,04 olup F VIII düzeyi \%7,2 olarak kaydedildi. Tam idrar incelemesinde mikroskobik hematüri saptanmadi. Posteroanterior akciğer grafisi normal olarak değerlendirilen hastanın çekilen karşılaştırmalı kalça eklem grafisinde sağ tarafta kalça eklemi hizasında $4 \times 4 \mathrm{~cm}$ ebatlarında hematomla uyumlu radyoopak görünüm dikkat çekmekteydi (Şek. 1). Yapılan ultrasonografik incelemede sağ inguinal bölgede cilt altı dokuları arasında yaklaşık $40 \times 37 \mathrm{~mm}$ boyutlarında nisbeten düzgün sınırlı, hematomu düşündüren, heterojen hipoekoik alan belirlendi. Pelvik bölgenin bilgisayarlı tomografi incelemesinde sağ inguinal bölgede cilt altında kas tabakasını da içine alan $4 \times 4$ cm'lik hematomla uyumlu görünüm saptandı (Şek. 2). Genel cerrahi ve dahiliye ile konsülte edilen hastaya genel cerrahinin ek önerisi olmamakla beraber dahiliye tarafından $2 \times 500$ Ünite F VIII uygulaması önerildi. Acil gözleme yatırılan ve günlük $2 \times 500$ Ünite F VIII tedavisi başlanan hastanın ikinci gün yapılan kontrol ultasonografisinde lezyon boyutlarında artış olmadı. Kan değerleri takibinde anormallik saptanmayan ve F VIII düzeyi \%54'e ulaşan hasta, 3 günlük izlemin ardından taburcu edildi.

\section{Tartışma}

X'e bağlı resesif geçişiyle erkekleri etkileyen ve en sık görülen kan pıhtılaşma bozukluğu olan hemofili A, yumuşak doku yaralanmalarından kemik kırıklarına kadar çeşitli klinik tablolar ile acil servis hekimlerinin karşısına çıkabilmektedir (Pelligra SJ., 1987; Connelly et al., 1998). Olgumuzda da sunulduğu üzere hemofili A hastalarının acil servise pek çok kere başvuru yaptıkları yakınmaları arasında yumuşak dokuda kanamanın neden olduğu şişlikler de bulunmaktadır. Hemofili A ve diğer pıhtılaşma faktörlerinin eksikliğine bağlı spontan kanama deyimi, ilgili bölgeye herhangi bir travma olmaksızın oluşan kanamaları tarif etmek için kullanılmaktadır (Heer et al., 2008). Faktör VIII düzeyinin \%1'in altında olduğu şiddetli hemofili vakalarında büyük eklemleri, kas dokusunu ve yumuşak dokuyu içine alan spontan kanama atakları görülebildiği bildirilmiştir (Kirbas et al., 2008). Tekrarlayan eklem ve kas içi kanamalar kontraktürlere ve deformitelere neden olmakta ve bu da hastanın normal fiziksel ve fonksiyonel işlevlerini bozmaktadır (Lancourt et al., 1977). Bu yüzden erken tanı ve tedavi hastaların ileriki yaşam konforları için de büyük önem taşımaktadır. Erken tanıda protrombin ve trombin zamanları değişmezken izole aktive PTT uzaması önem taşımaktadır (Jones EW., 1958; Wendling et al., 2003). Kanama zamanının normal kalması von Willebrand hastalığının ekarte edilmesine yardımcı olur. Diğer intrinsik yol faktörleri ve von Willebrand faktör düzeyi normal iken F VIII aktivitesi \%10'un altına düşer (Heer et al., 2008). Yine kanamaya bağ11 olarak hemoglobin değeri düşük saptanabilir (Wendling et al., 2003; Dauty et al., 2007). Hemofili hastalarının değerlen- dirilmesinde görüntüleme yöntemi olarak ultrasonografi ve bilgisayarlı tomografiden faydalanılmaktadır. Kas içine kanamalarda ultrasonografi kullanılabileceği gibi özellikle kompresyon ve kalsifikasyon gibi komplikasyon şüphesi varlığında ise bilgisayarlı tomografiden de faydalanılmaktadır (Dauty et al., 2007). Doğuştan kanama hastalığı bulunan ve kanama semptomlarıyla acil servise gelen hastalarda amaç; eksik olan pıhtılaşma faktörünün kan düzeyini yükseltmek olmalıdır. Birden fazla damar yolu açılarak gereğinde eksik faktör konsantreleriyle beraber sıvı ve kan replasmanı da hızlı ve eş zamanlı uygulanmalıdır. Tedavideki gecikmeler ekstremite kaybına ve hatta ölümlere yol açabileceğinden major kanamayla acil servise gelen hastalarda eksik pıhtılaşma faktörlerinin hızlıca yerine konması hatta tanısal laboratuar testlerinin faktör seviyesi yükseldikten sonraya bırakılması gerekir. Faktör temini, tipi ve dozu hakkında genellikle bu konularda tecrübeli ve donanımlı olan olan hasta ve hasta yakınlarından yardım almaktan çekinilmemelidir (Singleton et al., 2008). Faktör VIII'in bulunmadığı ya da temin edilene kadar çok zaman geçeceği düşünülen durumlarda taze donmuş plazma ve kriyopresipitat kullanılabilir (Pelligra SJ., 1987; Singleton et al., 2008). Ancak unutulmamalıdır ki bu ürünlerle istenen faktör düzeyini yakalamak zordur ve aşırı volüm yükü de sorun olarak karşımıza çıkabilir. Hastalar acil serviste kaldı̆̆ sürece aspirin içeren bileşiklerden, intramüsküler ve intraarteryel enjeksiyon gibi girişimlerden uzak durulmalıdır. Hastalığın kesin tedavisi için yapılan gen tedavileri hali ha-

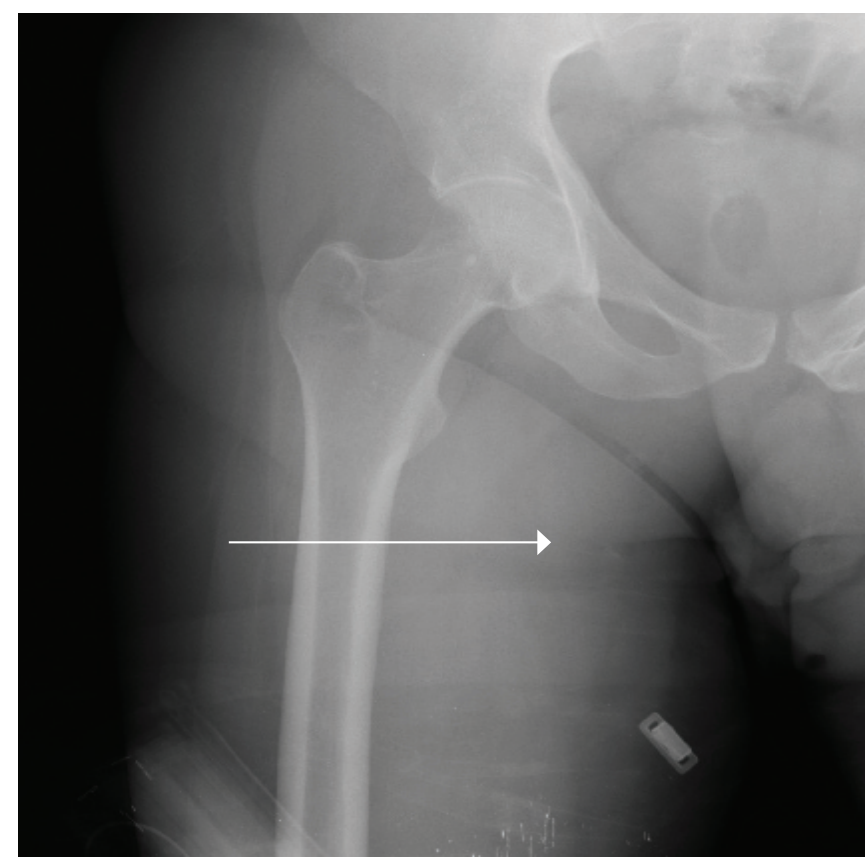

Şek. 1. Sağ inguinal bölgede $4 \times 4 \mathrm{~cm}$ ebadında radyoopak görünüm.
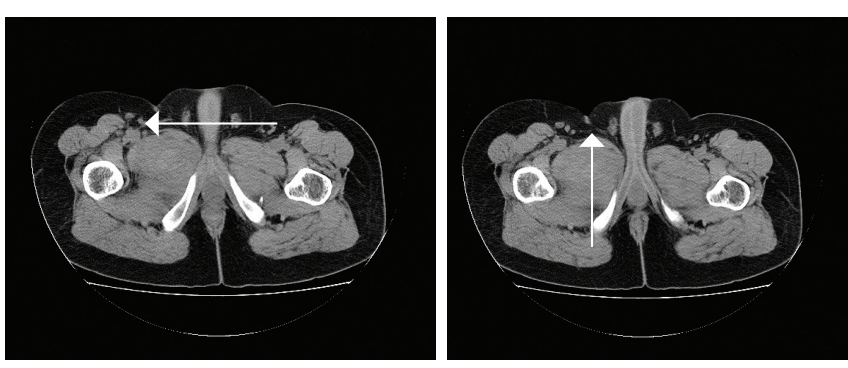

Şek. 2. Sağ uyluk proksimal medial komşuluğundaki addüktör kas yapılarında hacim ve dansitede artış (kas içi hemoraji) dikkat çekmektedir. 
zırda bilim insanlarının gündemindedir ve ilerisi için umut vermektedir (Nyugen et al., 2008).

\section{Sonuc}

Hemofili A en sık görülen konjenital pıhtılaşma bozuk- luğu olup hastalar acil servise kanamaya bağlı değişik klinik görünümlerle başvurabilir. Erken tanı ve uygun acil yönetimi hastaları hem akut hem de kronik komplikasyonlardan korumada önemli yer teşkil etmektedir.

\section{KAYNAKLAR}

Connelly, S., Kaleko, M., Hemophilia, A., 1988. Gene therapy. Hemophilia. 4, 380-388.

Dauty, M., Sigaud, M., Trossaërt, M.,2007. Iliopsoas hematoma in patients with hemophilia: A single-center study. Joint Bone Spine. 74, 179183.

Heer, J.S., Enriquez, E.G., Carter, A.J., 2008. Spinal epidural hematoma as first presentation of hemophilia A. J. Emerg. Med. 34, 159-162.

Jones, E.W., 1958. Mosculoskeletal complications of hemophilia. California Med. 4, 316-319.

Kirbas, I., Ozgul, E., Avci, Z., Coskun, M., Ozbek N., 2008. Ultrasound and computed tomography findings of spontaneous intramural hemorrhage of renal pelvis and ureter in patient with hemophilia A. Urology. 72, 1030-1032.

Lancourt, J.E., Gilbert, M.S., Posner, M.A., 1977. Management of bleeding and associated complications of hemophilia in the hand and forearm. J. Bone Joint Surg. Am. 59, 451-460.

Nyugen, A., Dow, A.C., Busuttil, R.W., Lipshutz, G.S., 2008. Promoter evaluation for efficient production of human factor VIII by gene therapy in a murine model of hemophilia A. J. Surg. Res. 144, 439.

Pelligra, S.J., 1987. Hemophilia: Pathophysiology and musculoskeletal complications. Southern Med. J. 80, 9.

Singleton, T., Kruse-Jarres, R., Leissinger, C., 2008. Emergency department care for patients with hemophilia and von Willebrand Disease. J. Emerg. Med. 30.

Wendling, D., Bertrand, M., 2003. Hemarthrosis in acquired hemophilia. Two case-reports Joint Bone Spine. 70, 532-534. 